\title{
PLATELET-RICH PLASMA (PRP) AND TRANEXAMIC ACID (TXA) APPLIED IN TOTAL KNEE ARTHROPLASTY
}

\author{
PLASMA RICO EM PLAQUETAS (PRP) E ÁCIDO TRANEXÂMICO \\ (ATX) APLICADOS NA ARTROPLASTIA TOTAL DO JOELHO
}

\author{
João Paulo Fernandes Guerreiro, ${ }^{1,2,3}$ Diogenes Rodrigues lima, ${ }^{2}$ Glaucia Bordignon, ${ }^{2}$ Marcus Vinicius Danieli, ${ }^{1,2,3}$ \\ alexandre Oliveira Queiroz, ${ }^{2}$ Daniele Cristina Cataneo ${ }^{3}$
}

1. Hospital de Ortopedia Uniort.e, Londrina, PR, Brazil.

2. Hospital Evangélico de Londrina, Londrina, PR, Brazil.

3. Universidade Estadual Paulista Júlio de Mesquita Filho, Botucatu, SP, Brazil.

\section{ABSTRACT}

Objective: To evaluate the efficacy of platelet-rich plasma (PRP) and tranexamic acid (TXA) applied in total knee arthroplasty. Methods: We selected and randomized 84 patients. TXA was applied in 23 patients, PRP in 20, and PRP in combination with TXA in 20. Hemoglobin was measured preoperatively and 24 and 48 hours postoperatively. The function questionnaire, pain scale and gain of knee flexion were monitored until the second postoperative year. Results: There was a difference $(p<0.01)$ in the decrease in hemoglobin 48 hours after surgery between the TXA group and the control and PRP groups. In terms of pain, the TXA group at 24 and 48 hours after surgery and the PRP group at 48 hours after surgery showed advantages ( $p<0.01$ ). Knee flexion gain in the first 24 hours postoperatively was better in the TXA group $(p<0.05)$. Conclusion: TXA was effective in lowering the drop in hemoglobin level, reducing pain and improving movement gain 48 hours after the procedure. PRP was not effective in reducing bleeding or improving knee function after arthroplasty, but provided better control of postoperative pain. Level of Evidence I, Randomized, blinded, prospective clinical trial.

Keywords: Arthroplasty, Replacement, Knee. Tranexamic Acid. Platelet-Rich Plasma. Hemorrhage. Pain.

\section{RESUMO}

Objetivo: Avaliar a eficácia do plasma rico em plaquetas (PRP) e do ácido tranexâmico (ATX) aplicados na artroplastia total do joelho. Métodos: Selecionamos e randomizamos 84 pacientes. ATX foi aplicado em 23 pacientes, PRP em 20, e PRP associado a ATX em 20. A hemoglobina foi medida no pré-operatório e nas 24 e 48 horas após a cirurgia. O questionário de função, a escala de dor e o ganho de flexão do joelho foram verificados até o segundo ano de pós-operatório. Resultados: Houve diferença( $p<0,01)$ na diminuição da hemoglobina 48 horas após a cirurgia entre o grupo ATX e os grupos controle e PRP. Na dor, o grupo ATX 24 e 48 horas após a cirurgia e o grupo PRP 48 horas após a cirurgia apresentaram vantagens $(p<0,01)$. 0 ganho de flexão do joelho nas primeiras 24 horas de pós-operatório foi melhor no grupo ATX $(p<0,05)$. Conclusão: O ATX foi eficaz na diminuição da queda da hemoglobina, reduzindo a dor e melhorando o ganho de movimento em 48 horas após o procedimento. O PRP não foi eficaz na redução do sangramento ou na melhora da função do joelho após a artroplastia, mas proporcionou melhor controle da dor pós-operatória. Nível de Evidência I, Randomizado, duplo cego, ensaio clínico prospectivo.

Descritores: Artroplastia do Joelho. Ácido Tranexânio. Plasma Rico em Plaquetas. Hemorragia. Dor.

Citation: Guerreiro JPF, D Lima, G Bordignon, MV Danieli, AO Queiroz, DC Cataneo. Platelet-rich plasma (prp) and tranexamic acid (TXA) applied in total knee arthroplasty. Acta Ortop Bras. [online]. 2019;27(5):248-51. Available from URL: http://www.scielo.br/aob.

\section{INTRODUCTION}

In 2000, during the American Academy of Orthopedics meeting, for the first time, Mooar et al. ${ }^{1}$ demonstrated the use of autologous platelet gel in the postoperative period following total knee prosthesis with good results. Since 2006, studies on the use of PRP after TKA have presented conflicting results, and there is no consensus on its effectiveness. ${ }^{2-5}$ Similar to sealants such as fibrin, thrombin and PRP, antifibrinolytics have also been used to reduce bleeding. ${ }^{6-8}$ Tranexamic acid (TXA) is the most commonly used. ${ }^{9-11}$ The demonstrated results of intra-articular administration of TXA in TKA include effectively decreasing the reduction in hemoglobin $(\mathrm{Hb})$, blood loss due to drainage and the need for transfusion within 48 hours after surgery.12 Currently, TXA seems to be the most effective method to reduce bleeding. Nonetheless, TXA is not directly related to healing, and its efficacy in pain control and postoperative knee function improvement has not been demonstrated. The hypothesis of this study is that PRP combined with TXA is effective in controlling bleeding and pain and improves healing and function after TKA.

All authors declare no potential conflict of interest related to this article.

Work conducted at the Santa Casa de Londrina and Hospital Evangélico de Londrina.

Correspondence: João Paulo Fernandes Guerreiro. 2600 Higienópolis Av. Londrina, Paraná, Brazil,CEP: 86050170. joaoguerreiro39@yahoo.com.br 


\section{OBJECTIVE}

To evaluate the effectiveness of PRP and TXA in TKA in relation to the decrease in $\mathrm{Hb}$ levels, postoperative pain control, knee flexion gain and lower limb function gain.

\section{MATERIAL AND METHODS}

\section{Study design}

Randomized, blinded, prospective clinical trial

\section{Sample size}

Eighty-four patients

\section{Follow-up time}

Two years

\section{Study stages}

a) The project was approved by the Institution's Ethics and Research Committee under protocol number 634815 and clinical trial number RBR-9b4qga

b) Patient selection:

Inclusion criteria: three-compartment osteoarthritis of the knee; both sexes; indication for total knee prosthesis surgery and awaiting scheduling of the procedure; no diagnosis of inflammatory disease; and no history of atrial fibrillation, deep vein thrombosis or previous pulmonary embolism.

Exclusion criteria: a diagnosis of inflammatory disease; use of anticoagulant medications up to seven days before surgery; previous surgeries in the same knee; inadequate closure of the joint capsule; and no possibility of postoperative clinical follow-up.

All selected patients signed an informed consent form.

c) Randomization:

Random numbers were used for randomization. The patients were not informed of the group to which they were assigned until the end of the study.

d) Definition of groups:

Control (21 patients): total knee prosthesis and intra-articular application of saline only.

Experimental TXA (23 patients): total knee prosthesis and intra-articular TXA application.

Experimental PRP (20 patients): total knee prosthesis and intra-articular PRP application.

Experimental PRP + TXA (20 patients): total knee prosthesis and intra-articular application of PRP and TXA.

e) PRP preparation:

PRP was prepared by a duly trained professional. A total of 20 $\mathrm{mL}$ of blood was collected from patients in $5-\mathrm{mL}$ vacuum tubes with $10 \%$ sodium citrate for anticoagulation. The tubes were centrifuged (FANEM ${ }^{\circledR}$, Guarulhos, Sao Paulo, Brazil) at 1200 rotations per minute (RPM) for 10 minutes at room temperature in a $6.5-\mathrm{cm}$ radius centrifuge. This centrifugation allowed the separation of the blood into the following components: red blood cells (tube bottom), white cells (thin layer over red blood cells) and plasma (superficial layer). The plasma was transferred to another $10-\mathrm{mL}$ sterile tube and was centrifuged in the same centrifuge at the same speed for five minutes. At the end of this second centrifugation, the upper plasma layer (approximately $50 \%$ ) was discarded because of the small amount of platelets present. The lower portion, which is rich in platelets and called PRP, was placed in a sterile Petri dish on a surgical drape and placed in a syringe for application by the surgeon. (Figure 1) Every five patients, part of the prepared PRP was separated and subjected to platelet count analysis in automatic counters (ADVIA 120 Siemens $^{\circledR}$, Berlim and Munique, Germany).

f) Tranexamic acid:

The TXA treatment dose used was $1 \mathrm{~g}$ (four ampoules with $5 \mathrm{~mL}$ each and $50 \mathrm{mg} / \mathrm{mL}$ concentration) and was administered topically based on previous studies. ${ }^{13}$ After cleaning the joint cavity, $20 \mathrm{~mL}$ TXA was applied and maintained for 5 minutes before the joint capsule and wound were closed. (Figure 2)

Data collection (Table 1)

\section{Statistical analysis}

The statistical power of the sample was calculated using the sampsicommand of STATA software (version 11, 2011, College Station, Texas, USA),based on the method proposed by Frison and Pocock ${ }^{14}$ for a comparative design of groups with repeated measures and using the reduction in $\mathrm{Hb}$ levels as the parameter. By adopting a significance

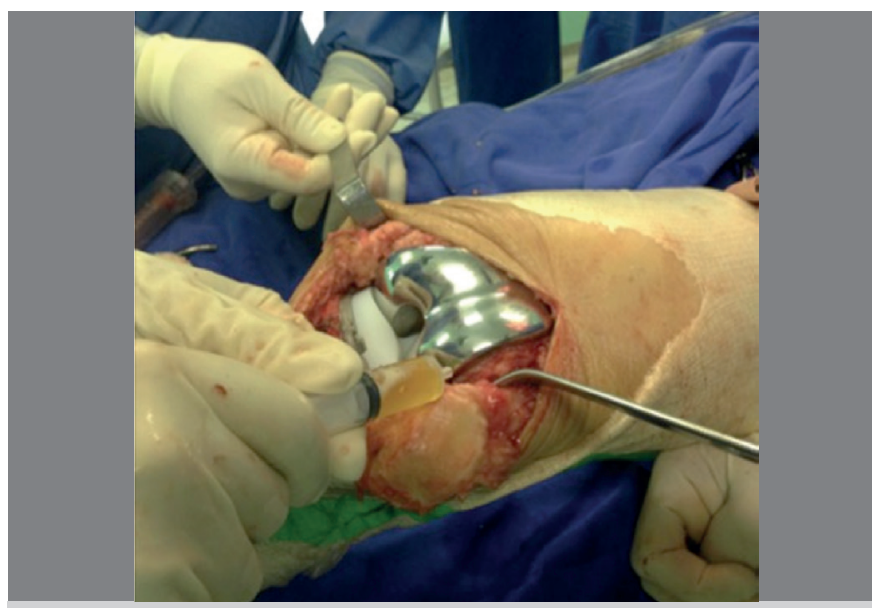

Figure 1. PRP Application in the Joint Cavity.

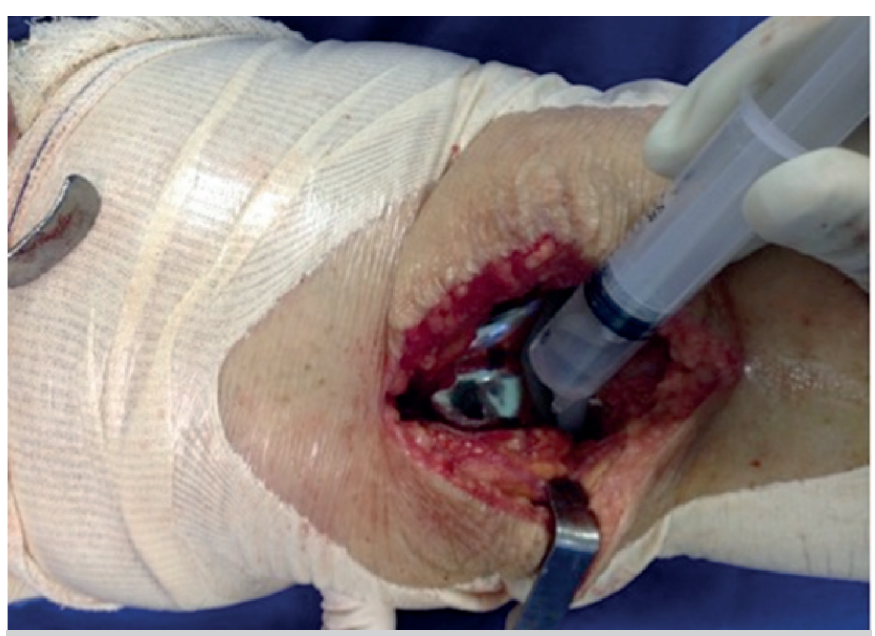

Figure 2. Application of TXA in the Joint Cavity.

Table 1. Model of the Worksheet Used to Collect Data on the Analyzed Parameters at the Different Time Intervals (before and after Surgery).

\begin{tabular}{c|c|c|c|c|c|c|c|c|c}
\hline & Before & $\mathbf{2 4} \mathrm{h}$ & $\mathbf{4 8} \mathrm{h}$ & $\mathbf{7}$ days & $\begin{array}{c}\mathbf{2 1} \\
\text { days }\end{array}$ & $\begin{array}{c}\mathbf{2} \\
\text { months }\end{array}$ & $\begin{array}{c}6 \\
\text { months }\end{array}$ & $\begin{array}{c}\mathbf{1} \\
\text { year }\end{array}$ & $\begin{array}{c}\mathbf{2} \\
\text { years }\end{array}$ \\
\hline $\mathrm{Hb}$ & $\mathrm{X}$ & $\mathrm{X}$ & $\mathrm{X}$ & & & & & & \\
\hline Knee flexion & & $\mathrm{X}$ & $\mathrm{X}$ & $\mathrm{X}$ & $\mathrm{X}$ & $\mathrm{X}$ & $\mathrm{X}$ & $\mathrm{X}$ & $\mathrm{X}$ \\
\hline Pain & & $\mathrm{X}$ & $\mathrm{X}$ & $\mathrm{X}$ & $\mathrm{X}$ & $\mathrm{X}$ & $\mathrm{X}$ & $\mathrm{X}$ & $\mathrm{X}$ \\
\hline WOMAC & $\mathrm{X}$ & & & & & $\mathrm{X}$ & $\mathrm{X}$ & $\mathrm{X}$ & $\mathrm{X}$ \\
\hline Transfusion & & $\mathrm{X}$ & $\mathrm{X}$ & & & & & & \\
\hline Wound & & $\mathrm{X}$ & $\mathrm{X}$ & $\mathrm{X}$ & $\mathrm{X}$ & $\mathrm{X}$ & & & \\
\hline Signs of infection & & & & $\mathrm{X}$ & $\mathrm{X}$ & $\mathrm{X}$ & $\mathrm{X}$ & $\mathrm{X}$ & $\mathrm{X}$ \\
\hline
\end{tabular}

Hb: hemoglobin; pain: numerical pain scale; WOMAC: Western Ontario and McMaster Universities Index; transfusion: assessed the need for blood transfusion; wound: observed healingdelay; signs of infection: serum tests were collected, and the need for antibiotic therapy, surgical debridement or removal of the implant was evaluated. 
level of $5 \%$ and varying the power of the test, it was concluded that 20 patients per group would ensure at least $95 \%$ power for the comparisons. Comparisons among the groups in relation to the variable $\mathrm{Hb}$ reduction were performed through analysis of variance (ANOVA). Tukey's posttest for multiple comparisons was used when relevant. ${ }^{15}$

\section{RESULTS}

Demographic Data (Table 2) and Preoperative and Prepared PRP Platelet Counts (Table 3).

Table 4 shows that there was a significant difference $(p<0.01)$ in decreased $\mathrm{Hb}$ at 48 hours after surgery among the groups.

Table 2. Demographic Data.

\begin{tabular}{c|c|c|c|c}
\hline & $\begin{array}{c}\text { Control } \\
\text { group }\end{array}$ & $\begin{array}{c}\text { TXA } \\
\text { group }\end{array}$ & $\begin{array}{c}\text { PRP } \\
\text { group }\end{array}$ & $\begin{array}{c}\text { PRP+TXA } \\
\text { group }\end{array}$ \\
\hline Number of operated patients & 21 & 23 & 20 & 20 \\
\hline $\begin{array}{c}\text { Number of patients } \\
\text { followed up to 1 year }\end{array}$ & 21 & 22 & 19 & 20 \\
\hline $\begin{array}{c}\text { Number of patients } \\
\text { followed up to 2 years }\end{array}$ & 21 & 13 & 16 & 18 \\
\hline Mean age & 69.14 & 68.3 & 66.4 & 68.75 \\
$(55-81)$ & $(55-86)$ & $(50-79)$ & $(56-79)$ \\
\hline Sex (male/female) & $7 / 14$ & $5 / 18$ & $6 / 14$ & $8 / 12$ \\
\hline $\begin{array}{c}\text { Preoperative hemoglobin value } \\
\text { (mean and standard deviation) }\end{array}$ & $\begin{array}{c}12.19 \\
(1.6)\end{array}$ & $\begin{array}{c}12.4 \\
(1.26)\end{array}$ & $\begin{array}{c}11.61 \\
(1.41)\end{array}$ & $\begin{array}{c}12.41 \\
(1.67)\end{array}$ \\
\hline $\begin{array}{c}\text { Preoperative WOMAC score } \\
\text { (mean and standard deviation) }\end{array}$ & $\begin{array}{c}73.52 \\
(5.25)\end{array}$ & $\begin{array}{c}77.48 \\
(7.77)\end{array}$ & $\begin{array}{c}73.2 \\
(5.94)\end{array}$ & $\begin{array}{c}75.4 \\
(8.69)\end{array}$ \\
\hline
\end{tabular}

Table 3. Preoperative and Prepared PRP Platelet Counts

\begin{tabular}{c|c|c|c}
\hline Platelet count & $\begin{array}{c}\text { Serum platelet } \\
\text { amount }\end{array}$ & $\begin{array}{c}\text { PRP platelet } \\
\text { amount }\end{array}$ & $\begin{array}{c}\text { Fold increase in } \\
\text { concentration }\end{array}$ \\
\hline Patient 1 PRP group & 200,000 & 550,000 & 2.75 \\
\hline Patient 6 PRP group & 277,000 & 620,000 & 2.23 \\
\hline Patient 11 PRP group & 155,000 & 480,000 & 3.1 \\
\hline Patient 16 PRP group & 416,000 & 880,000 & 2.11 \\
\hline Patient 1 PRP + TXA group & 183,000 & 450,000 & 2.45 \\
\hline Patient 6 PRP + TXA group & 238,000 & 513,000 & 2.15 \\
\hline Patient 11 PRP + TXA group & 295,000 & 834,000 & 2.82 \\
\hline Patient 16 PRP + TXA group & 174,000 & 621,000 & 3.56 \\
\hline Total & $1,938,000$ & $4,948,000$ & 2.55 \\
\hline
\end{tabular}

The TXA groupswere compared with the control group and PRP group, and there were no differences between the TXA group and TXA + PRP group. In the pain evaluation, compared with the control group, the TXA groups showed significant advantages in the evaluations at 24 and 48 hours after surgery, and the PRP group showed advantages in the evaluation at 48 hours after surgery $(p<$ $0.01)$. The flexion gains in the first 24 hours after surgery were better in the TXA groups than in the PRP and control groups $(p<0.05)$, with no difference between the TXA group and TXA + PRP group. In the evaluations of the decrease in $\mathrm{Hb}$ in the first 24 hours, pain in the first week, flexion gain in the first 48 hours and WOMAC function questionnaire scores in the second month, there were no differences among the four groups up to 2 years after surgery. (Table 4)

During the follow-up of the 84 patients, five cases (5.9\%) of wound dehiscence and superficial infection were successfully treated with dressings and oral antibiotics (two in the control group, two in the TXA and one in the PRP + TXA group). Two cases (2.4\%) of acute deep infection were treated, which required debridement, removal of the implant and two-step review of TKA with good progression (both in the PRP group). Two cases (2.4\%) of late deep infection (after the third postoperative month) were also treated, with a two-step review of TKA with good progression (one in the TXA group and one in the PRP). In one case (1.2\%), a review was indicated for patellar replacement, which was not performed in any of the primary surgeries. In total, five (5.9\%) reviews were performed over a two-year period. Three manipulations were performed to treat arthrofibrosis (one in the TXA group, one in the PRP group and one in PRP + TXA group). No cases required a blood transfusion (the transfusion criterion was a $\mathrm{Hb}$ value less than $7 \mathrm{mg} / \mathrm{dL}$ in symptomatic patients). There were no diagnosed cases of thrombosis or thromboembolism. The identified complications were not significantly associated with PRP or TXA among the groups. (Table 5)

\section{DISCUSSION}

To the best of our knowledge, no studies have yet evaluated the simultaneous use of TXA and PRP in TKA. Thus, in this study, we sought to combine the healing and anti-inflammatory effects of PRP with the hemostatic effect of TXA. This discussion is based on previous studies in which these substances were used alone in TKA. Administration of $1 \mathrm{~g}$ topical TXA alone or in combination with PRP is effective at reducing bleeding, based on the reduction in the $\mathrm{Hb}$

Table 4. Comparison among Groups.

\begin{tabular}{|c|c|c|c|c|c|}
\hline & $\begin{array}{c}\text { Control group } \\
\text { (mean and standard deviation) }\end{array}$ & $\begin{array}{c}\text { TXA group } \\
\text { (mean and standard deviation) }\end{array}$ & $\begin{array}{c}\text { PRP group } \\
\text { (mean and standard deviation) }\end{array}$ & $\begin{array}{c}\text { PRP + TXA group } \\
\text { (mean and standard deviation) }\end{array}$ & $P$ value \\
\hline $\mathrm{Hb}$ drop 24 hours & $1.38(0.95)$ & $0.97(0.54)$ & $1.33(1.18)$ & $0.71(0.63)$ & $>0.05$ \\
\hline $\mathrm{Hb}$ drop 48 hours & $2.28(1.15)^{a}$ & $1.5(0.66)^{b}$ & $2.01(1.02)$ & $1.29(0.81)^{b}$ & $<0.01$ \\
\hline Mean pain 24 hours & $6.33(1.11)^{\mathrm{a}}$ & $5.3(1.92)^{b}$ & $5.45(1.47)$ & $4.9(2.43)^{b}$ & $<0.01$ \\
\hline Mean pain 48 hours & $3.81(1.08)^{\mathrm{a}}$ & $2.48(0.95)^{b}$ & $2.7(1.26)^{b}$ & $2.65(1.46)^{b}$ & $<0.01$ \\
\hline Mean pain 1 week & $2.38(0.67)$ & $1.83(0.94)$ & $1.65(0.88)$ & $1.8(1.58)$ & $>0.05$ \\
\hline Mean pain 3 weeks & $1.67(0.8)$ & $1.35(0.98)$ & $0.9(1.02)$ & $1.15(1.04)$ & $>0.05$ \\
\hline Mean pain 2 months & $1.33(0.73)$ & $0.96(1.07)$ & $0.5(0.83)$ & $0.65(1.04)$ & $>0.05$ \\
\hline Mean pain 6 months & $0.95(0.8)$ & $0.48(0.9)$ & $0.55(0.83)$ & $0.25(0.55)$ & $>0.05$ \\
\hline Mean pain 1 year & $0.29(0.56)$ & $0.36(1.05)$ & $0.63(1.38)$ & $0.15(0.49)$ & $>0.05$ \\
\hline Mean pain 2 years & $0.14(0.36)$ & $0.77(1.48)$ & $0.24(0.97)$ & $0.39(0.7)$ & $>0.05$ \\
\hline Flexion gain 24 hours & $\frac{.17 / 0.00 /}{62.86(11.89) \mathrm{a}}$ & $70.87(10.41) \mathrm{b}$ & $58(10.05) a$ & $\frac{0.075(12.4) b}{67.75}$ & $<0.05$ \\
\hline Flexion gain 48 hours & $80(8.37)$ & $80.43(9.28)$ & $76.5(6.71)$ & $78.75(9.16)$ & $>0.05$ \\
\hline Flexion gain 1 week & $86.67(7.13)$ & $88.04(8.49)$ & $87.5(8.96)$ & $89(9.12)$ & $>0.05$ \\
\hline Flexion gain 3 weeks & $95.48(8.2)$ & $94.57(9.16)$ & $93(10.81)$ & $97.5(10.58)$ & $>0.05$ \\
\hline Flexion gain 2 months & $97.38(9.17)$ & $99.13(11.35)$ & $100.25(14.55)$ & $103.5(13.48)$ & $>0.05$ \\
\hline Flexion gain 6 Months & $96.9(6.61)$ & $105.65(14.17)$ & $101.25(13.07)$ & $111(11.65)$ & $>0.05$ \\
\hline Flexion gain 1 year & $109.05(9.44)$ & $109.55(12.53)$ & $108.68(13.93)$ & $117.5(9.67)$ & $>0.05$ \\
\hline Flexion gain 2 years & $113.1(10.43)$ & $112.31(10.92)$ & $112.5(11.83)$ & $118.89(10.65)$ & $>0.05$ \\
\hline WOMAC 2 months & $36.05(4.59)$ & $42.74(12.12)$ & $41.45(8.75)$ & $39.9(6.32)$ & $>0.05$ \\
\hline WOMAC 6 months & $20.9(5.16)$ & $20.57(5.87)$ & $20.9(9.36)$ & $18.55(4.72)$ & $>0.05$ \\
\hline WOMAC 1 year & $14.1(4.41)$ & $14.73(7.5)$ & $14.53(9.16)$ & $9.95(5.42)$ & $>0.05$ \\
\hline WOMAC 2 years & $10.05(4.25)$ & $11(7.31)$ & $8.94(6.57)$ & $10.17(5.93)$ & $>0.05$ \\
\hline
\end{tabular}


Table 5. Complications

\begin{tabular}{c|c|c|c|c|c}
\hline & $\begin{array}{c}\text { Control } \\
\text { group }\end{array}$ & $\begin{array}{c}\text { TXA } \\
\text { group }\end{array}$ & $\begin{array}{c}\text { PRP } \\
\text { group }\end{array}$ & PRP+TXAgroup & Total \\
\hline $\begin{array}{c}\text { Wound dehiscence and } \\
\text { superficial infection }\end{array}$ & $2(9.5 \%)$ & $2(8.7 \%)$ & 0 & $1(5 \%)$ & $5(5.9 \%)$ \\
\hline $\begin{array}{c}\text { Acute deep infection } \\
\text { (up to 3 months) }\end{array}$ & 0 & 0 & $2(10 \%)$ & 0 & $2(2.4 \%)$ \\
\hline $\begin{array}{c}\text { Late deep infection } \\
\text { (after 3 months) }\end{array}$ & 0 & $1(4.3 \%)$ & $1(5 \%)$ & 0 & $2(2.4 \%)$ \\
\hline Needed review & 0 & $1(4.3 \%)$ & $4(20 \%)$ & 0 & $5(5.9 \%)$ \\
\hline $\begin{array}{c}\text { Manipulation due } \\
\text { to arthrofibrosis }\end{array}$ & 0 & $1(4.3 \%)$ & $1(5 \%)$ & $1(5 \%)$ & $3(3.5 \%)$ \\
\hline Transfusion & 0 & 0 & 0 & 0 & 0 \\
\hline Thromboembolism & 0 & 0 & 0 & 0 & 0 \\
\hline Total patients & $2(9.5 \%)$ & $4(17.3 \%)$ & $5(25 \%)$ & $2(10 \%)$ & $13(15 \%)$ \\
\hline
\end{tabular}

value, and this finding was once again confirmed in the present study. ${ }^{11-13}$ In published studies on TKA, the most common route of administration for TXA application is intravenous. In this study, PRP was not effective in reducing bleeding or enhancing the effect of TXA. Mochizuki et al. ${ }^{3}$ conducted a prospective, controlled, randomized clinical study with 315 knees that showed less bleeding through the drain and smaller decreases in Hb levels in patients in whom PRP was applied intra-articularly after capsule suture and activated with thrombin and calcium chloride. In the present study, PRP was applied with the joint still open and exposed with the intention of obtaining a better distribution of the substance. This more natural way may be beneficial for pain control. Moreover, this method may have delayed the effect of PRP at the time of major bleeding shortly after reperfusion as the substance had not reached its maximum effect for hemostasis. The preparation and application of PRP vary in the literature, constituting the main limitation for any systematic review or meta-analysis. Additionally, the results are conflicting. In a recent meta-analysis of 12 studies and 1,333 knees, no significant difference was found for the decrease in $\mathrm{Hb}$ in patients treated with $\mathrm{PRP}^{4}$ In this meta-analysis, there was also no evidence of improvements in knee range of motion or function, but pain was reduced with the use of PRP. Another meta-analysis published after the aforementioned one showed an improvement in the range of motion in cases where PRP was used but without advantages for pain control or function gain. ${ }^{5}$

The present study demonstrates that in addition to reducing bleeding, a good result can be achieved in the first 48 hours after the procedure with regard to pain and range of motion gain, but this finding did not remain in the outpatient evaluations performed in the first 2 months. Moreover, knee function gain analyzed using the WOMAC questionnaire did not increase within this time frame. Despite demonstrating that TXA was effective in reducing pain and promoting better movement gains in the first hours after the procedure, this study was performed in a single center with a relatively limited number of patients. Because this is the first prospective study demonstrating this result, other studies should be performed to better understand this effect.

The limitations of the present study include its design, which allowed the surgeon to know which patient belonged to each group during the surgery. The loss of TXA group presented more than $40 \%$ lost follow-up. It did not happen in the other groups and can create a huge bias. The loss of patients who did not complete the 2-year follow-up (19\%) and the lack of quantification of growth factors and the number of residual leukocytes in PRP samples are also aspects that may have limited the impact of our results.

\section{CONCLUSION}

In the first 48 hours after the procedure, TXA applied topically in TKA reduced the decrease in $\mathrm{Hb}$ levels, reduced pain and promoted better movement gain.

In this study, compared with the control, PRP was not effective in reducing bleeding or improving knee function after arthroplasty but provided better control of postoperative pain as measured by the pain scale in the first 48 hours after surgery.

Compared to their use individually, the combination of PRP and TXA led to a smaller decrease in $\mathrm{Hb}$ and better pain control in the first 48 hours after surgery, but their use in combination was not synergistic and did not enhance their individual effects.

AUTHORS' CONTRIBUTIONS: Each individual author contributed individually and significantly to development of this work. JPFG (0000-0002-2026-9176)* drafted and reviewed the article, performed statistical analysis and contributed to the intellectual concept of the study and the entire research project; DRL (0000-0002-0307-2582 *: drafted the article, sought volunteers and analyzed the data; GB (0000-0001-5273-4303)*:drafted the article, sought volunteers and analyzed the data; AOQ (0000-0003-2808-7892)*:reviewed the article and contributed to the intellectual concept of the study; MVD (0000-0001-7547-7557)*:reviewed the article and contributed to the intellectual concept of the study; DCC (0000-0002-3400-2309) reviewed the article and contributed to the intellectual concept of the study. *ORCID (Open Researcher and Contributor ID).

\section{REFERENCES}

1. Mooar PA, Gardner MJ, Klepchick PR. The efficacy of autologous platelet gel in total knee arthroplasty: an analysis of range of motion, hemoblobin, and narcotic requirements. Paper presented at the .American Academy of Orthopaedic Surgeons, 67th Annual Meeting; March 15-19; Orlando, Florida; 2000.

2. Horstmann WG, Slappendel R, van Hellemondt GG, Wymenga AW, Jack N, Everts PA. Autologous platelet gel in total knee arthroplasty: a prospective randomized study. Knee Surg Sports Traumatol Arthrosc. 2011;19(1):115-21.

3. Mochizuki T, Yano K, Ikari K, Hiroshima R, Kawakami K, Koenuma N, et al Platelet-rich plasma for the reduction of blood loss after total knee arthroplasty: a clinical trial. Eur J Orthop Surg Traumatol. 2016;26(8):901-5.

4. Kuang MJ, Han C, Ma JX, Li F, Zhao J, Fu L, et al. The efficacy of intraoperative autologous platelet gel in total knee arthroplasty: a meta-analysis. Int J Surg. 2016;36(A):56-65.

5. Li FX, Li Y, Qiao CW, Zhu J, Chen J, Zhang PY. Topical use of platelet-rich plasma can improve the clinical outcomes after total knee arthroplasty: a systematic review and meta-analysis of 1316 patients. Int J Surg. 2017:38:109-16.

6. Henry DA, Carless PA, Moxey AJ, O'Connell D, Stokes BJ, Fergusson DA, et al. Anti-fibrinolytic use for minimising perioperative allogeneic blood transfusion. Cochrane Database Syst Rev, 2011:16:CD001886.

7. Kagoma YK, Crowther MA, Douketis J, Bhandari M, Eikelboom J, Lim W. Use of antifibrinolytic therapy to reduce transfusion in patients undergoing orthopedic surgery: a systematic review of randomized trials. Thromb Res. 2009;123(5):687-96.

8. Helito CP, Gobbi RG, Castrillon LM, Hinkel BB, Pécora JR, Camanho GL. Comparison of Floseal( $r$ ) and electrocautery in hemostasis after total kneearthroplasty. Acta Ortop Bras. 2013;21(6):320-2

9. Dunn CJ, Goa KL. Tranexamic acid: a review of its use in surgery and other indications. Drugs. 1999;57(6):1005-32.

10. Alshryda S, Sarda P, Sukeik M, Nargol A, Blenkinsopp J, Mason JM. Tranexamic acid in total knee replacement: a systematic review and meta-analysis. J Bone Joint Surg Br. 2011:93(12):1577-85.

11. Panteli M, Papakostidis C, Dahabreh Z, Giannoudis PV. Topical tranexamic acid in total knee replacement: a systematic review and meta-analysis. Knee. 2013;20(5):300-9

12. Cid J, Lozano M. Tranexamic acid reduces allogeneic red cell transfusions in patients undergoing total knee arthroplasty: results of a meta-analysis of randomized controlled trials. Transfusion. 2005;45(8):1302-7.

13. Georgiadis AG, Muh SJ, Silverton CD, Weir RM, Laker MW. A prospective double-blind placebo controlled trial of topical tranexamic acid in total knee arthroplasty. J Arthroplast. 2013;28(8 Suppl):78-82.

14. Frison L, Pocock SJ. Repeated measures in clinical trials: analysis using mean summary statistics and its implications for design. Stat Med. 1992:11(13):1685-704.

15. Montgomery DC. Design and analysis of experiments. 5th ed. New York, NY John Wiley \& Sons; 2000 